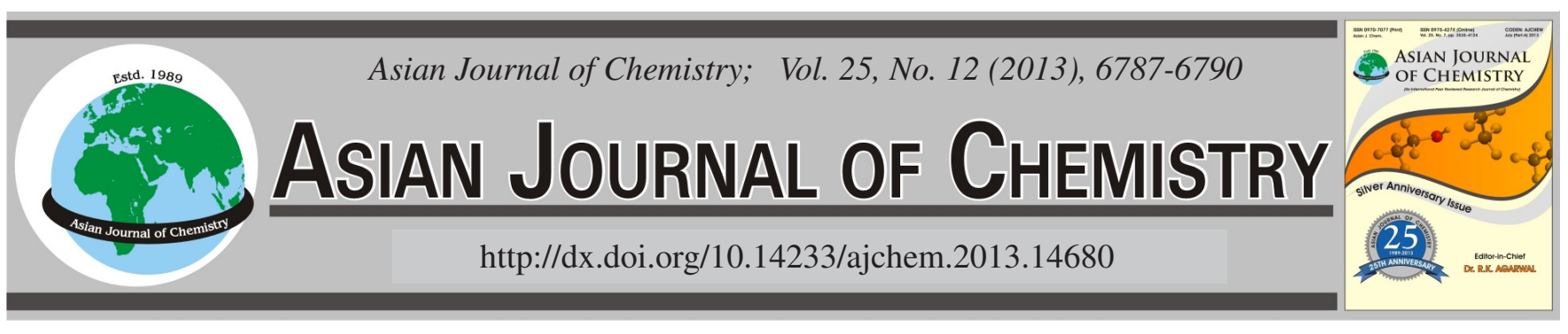

\title{
Acaricidal Activity of Essential Oils from Tulsi (Ocimum basilicum), Bach (Acorus calamus) and Mint (Mentha arvensis) Against Rhipicephalus sanguineus (Latreille)
}

\author{
Farkhanda Manzoor $^{1, *}$, Sabiha Fazal ${ }^{1}$, Neelma Munir ${ }^{2}$, Shugufta Naz ${ }^{2}$ and Anam Khalid ${ }^{1}$
}

${ }^{1}$ Department of Zoology, Lahore College for Women University, Lahore, Pakistan

${ }^{2}$ Department of Biotechnology and Microbiology, Lahore College for Women University, Lahore, Pakistan

*Corresponding author: E-mail: doc_farkhanda@yahoo.com

(Received: 15 October 2012;

Accepted: 3 June 2013)

AJC-13572

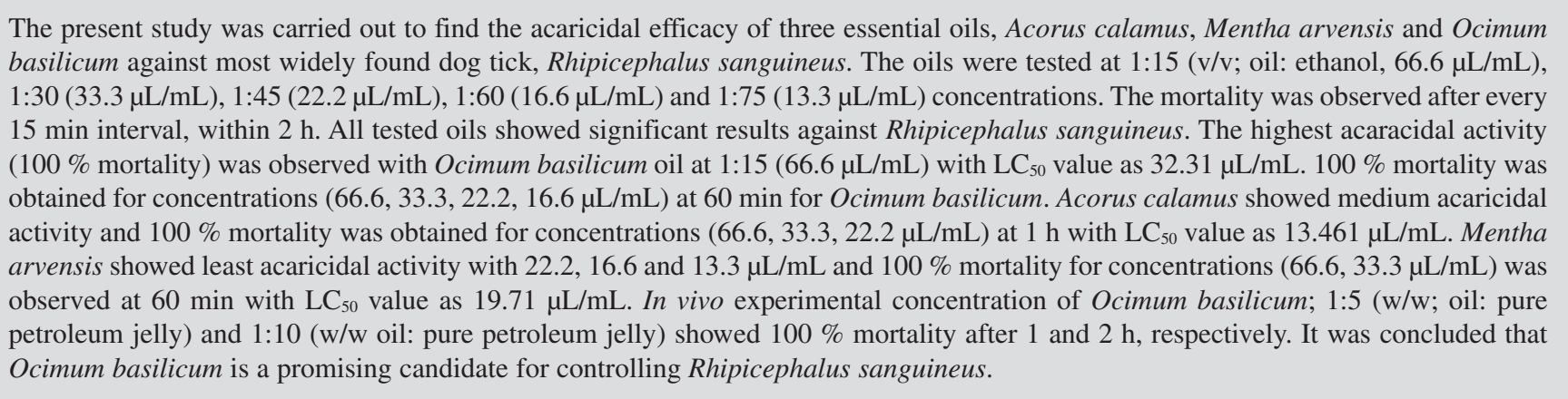

Key Words: Acaricidal activity, Essential oils, Latreille.

\section{INTRODUCTION}

Ticks are arthropods of great medical and veterinary significance. They can cause direct damage due to their feeding behaviour as they are blood feeding parasites and also act as a vector of disease agents. Ticks are among the most important vectors of disease agents affecting companion animals, livestock and humans ${ }^{1-8}$. It is estimated that out of 899 species of ticks ${ }^{9}$ only $10 \%$ are involved in the transmission of different types of pathogens such as viruses, bacteria, protozoa and filarial nematodes ${ }^{1,5}$.

Rhipicephalus sanguineus, brown dog tick, that can be found almost worldwide, is a usual ectoparasite of domestic dogs. It can be found on a diverse variety of wild and domestic animals including humans but feeds primarily on $\operatorname{dogs}^{10,11} . R$. sanguineus is vector of pathogens such as Babesia canis and Ehrlichia canis, the etiological agents of canine babesiosis and canine monocytic ehrlichiosis, respectively. In Maxico, $R$. sanguineus is vector of Rickettsia rickettsii, the etiological agent of Rocky Mountain spotted fever in rural eastern Arizona ${ }^{12}$ and maybe elsewhere ${ }^{13}$.

Dogs can be treated with a wide range of veterinary preparations for example spot-on formulations, shampoos, impregnated collars, dips and powders ${ }^{14}$. For controlling $R$. sanguineus, carbaryl, fipronil, amitraz and pyrethroids (cypermethrin, permethrin and deltamethrin) are among the most frequently used acaricides ${ }^{15-17}$.

Over the years, the extensive uses of acaricides have lead to the resistant tick selection. Acaricide resistance development is a serious problem over the world and is well documented for other species of ticks as well, such as Rhipicephalus (Boophilus) microplus (syn. Boophilus microplus) ${ }^{18}$. According to one study carried out in Panama, $R$. sanguineus ticks were highly resistant to DDT, permethrin, and coumaphos; to some extent resistant to amitraz and not resistant to fipronil ${ }^{19}$. In a study carried out in Spain, 15 different $R$. sanguineus populations were used and found that they were low to moderate resistant against propoxur, highly resistant to deltamethrin and showed no resistance against amitraz. The results of studies carried out in Brazil show that deltamethrin is not a method of choice for $R$. sanguineus tick population. These studies indicate that the resistance against a given acaricide may differ among different populations and some $R$. sanguineus populations appear to have high resistance against prethroid acaricides ${ }^{20}$. 
Long term use and misuse of acaricides is likely the main factor influencing the development of resistance in ixodid ticks. Several mechanisms have been suggested to explain the development of acaricide resistance in ticks e.g., target site mutation $^{21,22}$. The mechanisms of development of resistance in $R$. sanguineus ticks are poor understood and need further research.

When thinking about the control of ticks, one thing should be kept in mind that only ca. $5 \%$ ticks are on the dog and remaining $c a .95 \%$ are present in the environment. So, the use of acaricide in the environment in which dog lives, is necessary. The using of acaricides can be effective for a restricted period of time. The long term and misuse of acaricides in the environment has lead to the serious environmental pollution and acaricidal resistance in ticks ${ }^{23}$. Natural products can be considered as a valuable alternative. A large number of plant derivatives have been reported to have acaricidal effect, showing wide range of activities including activities against diverse stages of ticks and many species of ticks ${ }^{24-26}$.

As the improper use of acaricides are causing environmental pollution and toxicity to humans and other nontargeted organisms (e.g., predators and prey of ticks). The misuse of acaricides is also producing resistant ticks. In the light of all the side effects of chemical acaricides, the objectives of present study are to: - Test the plant oils as an acaricidal agent against $R$. sanguineus. $\bullet$ Evaluate the most effective plant oil against $R$. sanguineus. $\bullet$ Introduce the safer, environmental friendly and effective oil on the naturally infested dogs. - Introduce an economical method for control of $R$. sanguineus.

Literature reports that there has been no study carried out in Pakistan to test the efficacy of Acorus calamus, Mentha arvensis and Ocimum basillicum on the Rhipicephalus sanguineus species. So, the present study was conducted for the first time to test their toxic effects against $R$. sanguineus. The present study would be a step forward to future research on Rhipicephalus sanguineus.

\section{EXPERIMENTAL} tick).

Test organism: Rhipicephalus sanguineus (Brown dog

Plant collection: Plants were collected from their natural habitat. The plants were selected on the basis of their insecticidal properties and ethno-veterinary importance. The plant species were identified by the Department of Botany, Lahore College for Women University, Lahore and then used for the extraction of oils. Rhizome of Acorus calamus (Bach), leaves of Mentha arvensis (Mint) and Ocimum basilicum (Tulsi) were used for the present study.

Extraction of essential oils: The plant material was washed, dried, crushed, weighed and placed in the distillation flask. Oil was extracted by steam distillation (Reverse DeanStark method).

Measurement of physical properties of essential oils: Solubility, specific gravity, refractive index, acid values and easter values of oil were determined according to the standard procedures.

Tick collection: $R$. sanguineus ticks were collected from Dog Hospital, University of Veterinary and Animal Sciences
(UVAS), Lahore. Ticks were collected from naturally infested dogs.

Collection technique: For the safe collection of ticks, following method was applied as described by Zajac et al. ${ }^{27}$.

(1) Fine forcep was used to grasp the tick as close to the skin as possible. (2) With steady and even pressure, tick was pulled upward without jerk and twist (twist and jerk can cause the mouth-parts to break off and left in the skin). (3) After removing the tick, the bite area was thoroughly cleaned.

Identification: After collection, identification of tick was performed in laboratory. Adult $R$. sanguineus ticks including male ticks and engorged females were selected for practical work. Identification was performed with the help of a magnifying glass, by following Dichotomous key (Veterinary Clinical Parasitology by Ribeiro et $a l^{28}$.

Rearing: Rearing of $R$. sanguineus tick was performed by using the method described by Bicalho et al. ${ }^{29}$.

Acaricidal assay: Acaricidal assay was performed in order to find out the toxicity of different concentrations of oils on adult stages of $R$. sanguineus. 30 ticks, including 15 males and 15 females were selected for the present study. The control group also contains 30 adult ticks and was treated with the tap water. Ticks were used within $24 \mathrm{~h}$ of collection. These concentrations were screened against laboratory reared ticks by using adult immersion test (AIT).

Adult immersion test (AIT): For the present study, adult immersion test method was selected as described by Ghosh et $a l .^{30}$, with minor modifications. The experimental group was washed with the distilled water and kept on the dry filter paper. After that, they were immersed in the required concentrations for $2 \mathrm{~min}$ and then transferred to the petri plates padded with the Whatmann filter paper No.1. The control group was immersed in the tap water for 2 min. Mortality was checked after every $15 \mathrm{~min}$ within $2 \mathrm{~h}$. Mortality of the ticks was made sure by three observations i.e., $\bullet$ By expose them to light and observing their pedal movements. $\bullet$ By touching their legs with a forcep and noticing their pedal movements. • By observing their darkness of cuticle.

The tick was considered as dead if there was no pedal movements observed after exposure to the light and touching with a forcep and with the darkness of cuticle.

In vivo application of Ocimum basilicum oil on naturally infested dogs: For application of most effective oil (Ocimum basilicum) on naturally infested dogs, 1:5 (oil: pure petroleum jelly; w/w) concentration and 1:10 (oil: pure petroleum jelly; w/w) concentration were prepared.

Method of application: The mixture of oil and pure petroleum jelly was applied on the area of dog's skin where the ticks were attached. This was applied by hand covered with gloves. Control dogs were treated with the petroleum jelly. The observations were recorded after $1 \mathrm{~h}$ and $2 \mathrm{~h}$. Specimens were collected in the petri dishes to ensure tick mortality. Mortality was confirmed by the method described above.

Statistical analysis: Percentage mortality was determined by Abbott's formula. The data was analyzed by two- way ANOVA using Graph Pad Prism version 4.0 for Windows, Graph Pad Software, San Diego California USA, (www. graphpad.com). $\mathrm{LC}_{50}$ values for oils at different time intervals 
were also calculated by EPA Probit analysis program (version 1.5). The Student-Newman-Keuls test was performed on the data to determine significant differences between concentrations within exposure time and between exposure times within concentration. The statistical calculations are applied at 15, 30, 45 and $60 \mathrm{~min}$ for each essential oil.

\section{RESULTS AND DISCUSSION}

Physical properties including colour, odor, yield, solubility, specific gravity, refractive index, acid values, ester values of Acorus calamus, Mentha arvensis and Ocimum basilicum oils are given in Table- 1 .

It is clear from the Table-2 that the Ocimum basilicum has the highest acaricidal activity for the Rhipicephalus sanguineus. The percentage mortality of $R$. sanguineus is higher at every time interval (15, 30, 45 and $60 \mathrm{~min})$. The comparison of $\mathrm{LC}_{50}$ values also showed that Ocimum basilicum has the highest activity. Analysis of variance by two-way ANOVA shows that the mortality of $R$. sanguineus is timedependant and dose-dependant, for all essential oils tested and there exist an interaction between time and concentration.

Today, insect pest management (IPM) has to face up to the economic and ecological consequences of the use of pest control measures ${ }^{31}$. Commercial pesticides have caused problems of resistance in targeted pests and poisoning of food chain by different paths. According to different reports, commercial and synthetic pesticides are hazardous not only for environment and beneficial insects but also for health of human beings ${ }^{32,33}$, that is why there is a lot of research for alternates that can save the environment and human beings. In different parts of the world, scientists are working for the establishment and development of plant-based pesticides, called as biopesticides, botanical pesticides, natural pesticides and phytopesticides ${ }^{34-42}$. Neem has been already used in the fields at different levels. But neem alone cannot commercially fulfill the requirements so there is a need to search out new plant-based pesticides. The biopesticides of Pakistan are Nimbokil, a product of PCSIR, Pakistan and Biosol, a product of International Centre for Chemical \& Biological Sciences (ICC\&BS), Pakistan ${ }^{43}$.

Essential oils have been used, since middle ages, for virucidal, bactericidal, fungicidal, insecticidal, antiparasitical, cosmetic and medicinal applications. Nowadays, it has applications in pharmaceutical, cosmetics, agricultural, sanitary and food industries. Because of its mode of extraction, usually by distillation by aromatic plants, they consist of a wide variety of volatile molecules such as phenol-derived aromatic components, aliphatic components, terpenes and terpenoids ${ }^{44}$. Essential oils can be used as an alternative to synthetic pesticides. The commercially used pesticides contains particular single active ingredient against pest. Generally, by detoxification of acetylcholinesterase enzyme gene, genetic resistance against single active ingredient develops ${ }^{45}$. While essential oil of any plant contains 35-40 pure compounds, such as 41 compounds are reported from the neem flowers by Siddiqui et $a .^{42}$. Therefore, genes get confused in development of resistance against multiple compounds in essential oil of any plant.

The $\mathrm{LC}_{50}$ values of three oils represents that Ocimum basilicum has the least $\mathrm{LC}_{50}$ value at every time interval (15, $30,45 \mathrm{~min}) . \mathrm{LC}_{50}$ values for concentrations $(66.6,33.3,22.2$, $16.6,13.3 \mu \mathrm{L} / \mathrm{mL}$ ) are $32.318,18.403$ and $13.312 \mu \mathrm{L} / \mathrm{mL}$ at 15,30 and $45 \mathrm{~min}$, respectively. Results from the present study

TABLE-1

PHYSICAL PROPERTIES OF Acorus calamus (BACH), Mentha arvensis (MINT) AND Ocimum basilicum (TULSI) OILS

\begin{tabular}{cccc}
\hline Physical property & Acorus calamus & Mentha arvensis & Ocimum basilicum \\
\hline Solubility & Soluble in $80 \%$ alcohol & Soluble in $70 \%$ alcohol & Soluble in $70 \%$ alcohol \\
Specific gravity & 1.0695 to $1.0795\left(\right.$ at $\left.23^{\circ} \mathrm{C}\right)$ & $0.89500-0.89900\left(\right.$ at $\left.25^{\circ} \mathrm{C}\right)$ & 0.89000 to $0.93000\left(\right.$ at $\left.25^{\circ} \mathrm{C}\right)$ \\
Refractive index & 1.5335 to 1.5589 (at $\left.23^{\circ} \mathrm{C}\right)$ & $1.44900-1.46200\left(\right.$ at $\left.20^{\circ} \mathrm{C}\right)$ & 1.47950 to $1.48950\left(\right.$ at $\left.20^{\circ} \mathrm{C}\right)$ \\
Acid value & 0.6 to 2.5 & 0.3 to 5 & 2.5 to 6.5 \\
Ester value & 2 to 12 & 210 to 255 & 10 to 20 \\
\hline
\end{tabular}

Means within a column (between concentration within expose time) followed by the same uppercase letter are not significant $(P \geq 0.05)$. Means within a row (between exposure time within concentration) followed by the same lowercase letter are not significant $(\mathrm{P} \geq 0.05)$. No control mortality at any exposure time.

\begin{tabular}{|c|c|c|c|c|c|c|c|c|c|c|c|c|}
\hline \multicolumn{13}{|c|}{$\begin{array}{l}\text { TABLE-2 } \\
\text { COMPARISON OF ACARICIDAL ACTIVITY OF Acorus calamus, Mentha arvensis AND } \\
\text { Ocimum basilicum AT DIFFERENT TIME INTERVALS (15, 30, 45 AND } 60 \mathrm{~min})\end{array}$} \\
\hline \multirow{4}{*}{$\begin{array}{l}\text { Concentrations } \\
(\mu \mathrm{L} / \mathrm{mL})\end{array}$} & \multicolumn{12}{|c|}{ Percentage mortality \pm SE } \\
\hline & \multicolumn{4}{|c|}{ Acorus calamus } & \multicolumn{4}{|c|}{ Mentha arvensis } & \multicolumn{4}{|c|}{ Ocimum basilicum } \\
\hline & \multicolumn{4}{|c|}{ Time (min) } & \multicolumn{4}{|c|}{ Time (min) } & \multicolumn{4}{|c|}{ Time (min) } \\
\hline & 15 & 30 & 45 & 60 & 15 & 30 & 45 & 60 & 15 & 30 & 45 & 60 \\
\hline 66.6 & $\begin{array}{l}100 \pm \\
0.0^{\mathrm{Aa}}\end{array}$ & $\begin{array}{l}100 \pm \\
0.0^{\mathrm{Aa}}\end{array}$ & $\begin{array}{l}100 \pm \\
0.0^{\mathrm{Aa}}\end{array}$ & $\begin{array}{l}100 \pm \\
0.0^{\mathrm{Aa}}\end{array}$ & $\begin{array}{l}30.0 \pm \\
0.5^{\mathrm{Ab}}\end{array}$ & $\begin{array}{l}100 \pm \\
0.0^{\mathrm{Aa}}\end{array}$ & $\begin{array}{l}100 \pm \\
0.0^{\mathrm{Aa}}\end{array}$ & $\begin{array}{l}100 \pm \\
0.0^{\mathrm{Aa}}\end{array}$ & $\begin{array}{l}100 \pm \\
0.0^{\mathrm{Aa}}\end{array}$ & $\begin{array}{l}100 \pm \\
0.0^{\mathrm{Aa}}\end{array}$ & $\begin{array}{l}100 \pm \\
0.0^{\mathrm{Aa}}\end{array}$ & $\begin{array}{l}100 \pm \\
0.0^{\mathrm{Aa}}\end{array}$ \\
\hline 33.3 & $\begin{array}{l}26.6 \pm \\
0.5^{\mathrm{Bc}}\end{array}$ & $\begin{array}{l}63.3 \pm \\
0.5^{\mathrm{Bb}}\end{array}$ & $\begin{array}{l}100 \pm \\
0.0^{\mathrm{Aa}}\end{array}$ & $\begin{array}{l}100 \pm \\
0.0^{\mathrm{Aa}}\end{array}$ & $\begin{array}{l}6.67 \pm \\
0.5^{\text {Bd }}\end{array}$ & $\begin{array}{l}36.6 \pm \\
0.5^{\mathrm{Bc}}\end{array}$ & $\begin{array}{l}66.6 \pm \\
0.5^{\mathrm{Bb}}\end{array}$ & $\begin{array}{l}100 \pm \\
0.0^{\mathrm{Aa}}\end{array}$ & $\begin{array}{l}40.0 \pm \\
0.5^{\mathrm{Bb}}\end{array}$ & $\begin{array}{l}100 \pm \\
0.0^{\mathrm{Aa}}\end{array}$ & $\begin{array}{l}100 \pm \\
0.0^{\mathrm{Aa}}\end{array}$ & $\begin{array}{l}100 \pm \\
0.0^{\mathrm{Aa}}\end{array}$ \\
\hline 22.2 & $\begin{array}{l}13.3 \pm \\
0.5^{\mathrm{Cd}}\end{array}$ & $\begin{array}{l}43.3 \pm \\
0.5^{\mathrm{Cc}}\end{array}$ & $\begin{array}{l}70.0 \pm \\
0.5^{\mathrm{Bb}}\end{array}$ & $\begin{array}{l}100 \pm \\
0.0^{\mathrm{Aa}}\end{array}$ & $\begin{array}{l}0.0 \pm \\
0.0^{\mathrm{Cd}}\end{array}$ & $\begin{array}{l}10.0 \pm \\
0.5^{\mathrm{cc}}\end{array}$ & $\begin{array}{l}30.0 \pm \\
0.5^{\mathrm{cb}}\end{array}$ & $\begin{array}{l}56.6 \pm \\
0.5^{\mathrm{Ba}}\end{array}$ & $\begin{array}{l}23.3 \pm \\
0.5^{\mathrm{Cc}}\end{array}$ & $\begin{array}{l}60.0 \pm \\
0.5^{\mathrm{Bb}}\end{array}$ & $\begin{array}{l}100 \pm \\
0.0^{\mathrm{Aa}}\end{array}$ & $\begin{array}{l}100 \pm \\
0.0^{\mathrm{Aa}}\end{array}$ \\
\hline 16.6 & $\begin{array}{l}0.0 \pm \\
0.0^{\mathrm{Dd}}\end{array}$ & $\begin{array}{l}16.6 \pm \\
0.5^{\mathrm{Dc}}\end{array}$ & $\begin{array}{l}56.6 \pm \\
0.5^{\mathrm{Cb}}\end{array}$ & $\begin{array}{l}80 \pm \\
0.5^{\mathrm{Ba}}\end{array}$ & $\begin{array}{l}0.0 \pm \\
0.0^{\mathrm{Cc}}\end{array}$ & $\begin{array}{l}0.0 \pm \\
0.0^{\mathrm{Dc}}\end{array}$ & $\begin{array}{l}13.3 \pm \\
0.5^{\mathrm{Db}}\end{array}$ & $\begin{array}{l}23.3 \pm \\
0.5^{\mathrm{Ca}}\end{array}$ & $\begin{array}{l}6.67 \pm \\
0.5^{\text {Dd }}\end{array}$ & $\begin{array}{c}36.6 \pm \\
0.5^{\mathrm{Cc}}\end{array}$ & $\begin{array}{l}76.6 \pm \\
0.5^{\mathrm{Bb}}\end{array}$ & $\begin{array}{l}100 \pm \\
0.0^{\mathrm{Aa}}\end{array}$ \\
\hline 13.3 & $\begin{array}{l}0.0 \pm \\
0.0^{\mathrm{Dc}}\end{array}$ & $\begin{array}{l}0.0 \pm \\
0.0^{\mathrm{Ec}}\end{array}$ & $\begin{array}{l}30.0 \pm \\
0.3^{\mathrm{Db}}\end{array}$ & $\begin{array}{l}50 \pm \\
0.5^{\mathrm{Ca}}\end{array}$ & $\begin{array}{l}0.0 \pm \\
0.0^{\mathrm{Cb}}\end{array}$ & $\begin{array}{l}0.0 \pm \\
0.0^{\mathrm{Db}}\end{array}$ & $\begin{array}{l}0.0 \pm \\
0.0^{\mathrm{Eb}}\end{array}$ & $\begin{array}{l}16.6 \pm \\
0.5^{\mathrm{Da}}\end{array}$ & $\begin{array}{l}0.0 \pm \\
0.0^{\mathrm{Ed}}\end{array}$ & $\begin{array}{l}23.3^{ \pm} \\
0.5^{\mathrm{Dc}}\end{array}$ & $\begin{array}{c}53.3 \pm \\
0.5^{\mathrm{Cb}}\end{array}$ & $\begin{array}{l}83.3 \pm \\
0.5^{\mathrm{Ba}} \\
\end{array}$ \\
\hline
\end{tabular}


appear to be the first demonstration of acaricidal activity of the Ocimum basilicum, Acorus calamus and Mentha arvensis essential oils specifically against the brown $\operatorname{dog}$ tick $R$. sanguineus. The results show that Ocimum basilicum oil shows high percentage mortality at every time interval $(15,30,45$ and 60 $\min$ ) and $\mathrm{LC}_{50}$ values are also the least one for $O$. basilicum oil.

At highest concentration, 1:15 (v/v) or $66.6 \mu \mathrm{L} / \mathrm{mL}$, both Ocimum basilicum and Acorus calamus showed $100 \%$ mortality. But only Ocimum basilicum oil was tested against Rhipicephalus sanguineus on naturally infested dogs. Two reasons behind are: firstly, the aroma of Acorus calamus oil is strong woodspicy. It is observed during the study that the odor is unpleasant to many people. Secondly, the oil of Ocimum basilicum is locally available and people of Pakistan have been using it in relieving muscular aches and pains. The people use it on skin and no irritation on skin has been observed. The Ocimum basilicum essential oil can, therefore, serve as a substitute for some expensive synthetic insecticides, which have toxic residual effects, at 1:5 (w/w) concentration of oil and pure petroleum jelly.

As an insecticide, the mode of action of essential oils or their constituents is not clear. Essential oils affect physiology of insect in diverse ways. The plant essential oils are lipophilic in nature which facilitates them to interfere with the basic biochemical, metabolic, physiological and behavioural functions of insects. It affects biochemical processes and specifically disrupts the endocrinologic balance in insect body ${ }^{46}$. In the present study, acaricidal activity of essential oils is attributed to their major components and the resulting antagonistic or synergistic action of different components. However, minor components may also contribute to the biocidal activity. Following order of acaricidal activity of the essential oil has been found in the present study:

Ocimum basilicum $>$ Acorus calamus $>$ Mentha arvensis

\section{REFERENCES}

1. J.H. Oliver Jr., Ann. Rev. Ecol. System., 20, 397 (1989).

D. Raoult and V. Roux, Clin. Microbiol. Rev., 10, 694 (1997).

A.F. Azad and B.C. Beard, J. Emerg. Infect. Dis., 4, 179 (1998)

P. Parola and D. Raoult, J. Clin. Infect. Dis., 32, 897 (2001).

F. Jongejan and G. Uilenberg, Parasitology, 129, S3 (2004)

M. Labuda and P.A. Nuttall, Parasitology, 129, S221 (2004).

7. P. Parola, C.D. Paddock and D. Raoult, Clin. Microbiol. Rev., 18, 719 (2005)

8. F. Dantas-Torres, L.A. Figueredo and S.P. Brandao-Filho, Rev. Soc. Bras. Med. Trop., 39, 64 (2006).

9. S.C. Barker and A. Murrell, Parasitology, 129, S15 (2004).

10. A. Estrada-Pena and F. Jongejan, J. Exp. Appl. Acarolog., 23, 685 (1999).

11. F. Dantas-Torres, Lancet Infect. Dis., 7, 724 (2007).

12. L.J. Demma, M.S. Traeger, W.L. Nicholson, C.D. Paddock, D.M. Blau, M.E. Eremeeva, G.A. Dasch, M.L. Levin, J. Singleton Jr., S.R. Zaki, J.E. Cheek, D.L. Swerdlow and J.H. McQuiston, New Eng. J. Med., 353, 587 (2005)
13. M.E. Wikswo, R. Hu, M.E. Metzger and M.E. Eremeeva, J. Med. Entomol., 44, 158 (2007).

14. G.I. Garris, Vet. Clin. North Am Small Anim. Pract., 21, 173 (1991).

15. A.D. Jernigan, T.L. McTier, C. Chieffo, C.A. Thomas, M.J. Krautmann, J.A. Hair, D.R. Young, C. Wang and T.G. Rowan, Vet. Parasitol., 91, 359 (2000).

16. D. Otranto, R.P. Lia, C. Cantacessi, G. Galli, P. Paradies, E. Mallia and G. Capelli, Vet. Parasitol., 130, 293 (2005).

17. World Health Organization, Pesticides and Their Application for the Control of Vectors and Pests of Public Health Importance, World Health Organization, Geneva, edn. 6, p. 114 (2006).

18. R.B. Davey, J.E. George and R.J. Miller, Vet. Parasitol., 139, 211 (2006).

19. R.J. Miller, J.E. George, F. Guerrero, L. Carpenter and J.B. Welch, J. Med. Entomol., 38, 298 (2001).

20. F. Dantas-Torres, Vet. Parasitol., 152, 173 (2008).

21. H. He, A.C. Chen, R.B. Davey and G.W. Ivie, Insect. Biochem. Mol. Biol., 32, 303 (2002).

22. L.D. Foil, P. Coleman, M. Eisler, H. Fragoso-Sanchez, Z. Garcia-Vazquez, F.D. Guerrero, N.N. Jonsson, I.G. Langstaff, A.Y. Li, N. Machila, R.J. Miller, J. Morton, J.H. Pruett and S. Torr, Vet. Parasitol., 125, 163 (2004).

23. N.V. Labarthe, Cad. Saude Publica, 10, 47 (1994).

24. L.M. Borges, P.H. Ferri, W.J. Silva, W.C. Silva and J.G. Silva, Med. Vet. Entomol., 17, 228 (2003).

25. G. Dietrich, M.C. Dolan, J. Peralta-Cruz, J. Schmidt, J. Piesman, R.J. Eisen and J.J. Karchesy, J. Med. Entomol., 43, 957 (2006).

26. G.R. Needham, Pediatrics, 75, 997 (1985).

27. A.M. Zajac and G.A. Conboy, Veterinary Clinical Parasitology, Blackwell Publishing, USA, edn. 7, pp. 210-214 (2006).

28. V.L.S. Ribeiro, . Toigo, S.A.L. Bordignon, K. Gonçalves and G. von Poser, Vet. Parasitol., 147, 199 (2007).

29. K.A. Bicalho, F. Ferreira, L.M.F. Borges and M.F.B. Ribeiro, Arq. Bras. Med. Vet. Zootec., 53, 548 (2001).

30. S. Ghosh, A.K. Sharma, S. Kumar, S.S. Tiwari, S. Rastogi, S. Srivastava, M. Singh, R. Kumar, S. Paul, D.D. Ray and A.K. Rawat, J. Parasitol. Res., 108, 361 (2010).

31. C. Regnault-Roger, Int. Pest Manag. Rev., 2, 25 (1997).

32. D.E. Ray and P.J. Forshaw, J. Toxicol. Clin. Toxicol., 38, 95 (2000).

33. M.F. Wilks, J. Toxicol. Clin. Toxicol., 38, 103 (2000).

34. B.P. Sexena and E.B. Rohdendorf, Experientia, 30, 1298 (1974).

35. S.P.S. Chauhan, A. Kumar, C.L. Singh and U.K. Pandey, Indian J. Entomol., 49, 532 (1987).

36. F.A. Muhammed, Z. Khan, S.N.H. Naqvi and J. Ahmad, Efficacy of Nerium indicum crude extract as compared with cypermethrin against adults of Piezodorus hyberni (Gmelin) (Hemiptera: Pentatomidae). Proc. 1st Int. Cong. Entomol., pp. 189-194 (1995).

37. N. Pathak, P.K. Mittal, O.P. Singh, D.V. Sagar and P. Vasudevan, Int. Pest Cont., 42, 53 (2000).

38. M.A. Azmi, Pak. J. Sci. Ind. Res., 47, 394 (2004).

39. T. Ahsan, I. Ahmad, N. Yasmeen, R. Tabassum, A. Azmi and M. Shoaib, Int. J. Biol. Biotechnol., 2, 951 (2005).

40. P.R. Verma, T. Subburaju and N. Balakrishnan, J. Nat. Remedies, 6, 157 (2006).

41. H. Yan-Zhang, Y. Chang-Ju, X. Dong, O.R. Akinkurolere and Y.J. YingJuan, Acta Entomol. Sin., 50, 118 (2007).

42. B.S. Siddiqui, S.T. Ali, M.T. Rajput, T. Gulzar, M. Rasheed and R. Mehmood, Nat. Prod. Res., 23, 271 (2009).

43. I.M. Sial, M.A. Kazmi, Q.B. Kazmi and S.N.H. Naqvi, Pak. J. Zool., 41, 235 (2009).

44. F. Bakkali, S. Averbeck, D. Averbeck and M. Idaomar, Food Chem. Toxicol., 46, 446 (2008).

45. Q. Ming-Jing, X. Xin-Jun, H. Zhao-Jun and J. Xiao-Jing, Chin. Bull. Entomol., 44, 191 (2007).

46. R.S. Rattan, J. Crop. Protec., 29, 913 (2010). 